УДК 811.111-26: 81'23

DOI https://doi.org/10.26661/2414-1135-2021-84-3

\title{
МЕХАНІЗМ СПРИЙНЯТТЯ АУДИТОРІЕЮ ХАРИЗМАТИЧНИХ ОЗНАК ПУБЛІЧНОЇ ОСОБИСТОСТІ
}

\author{
Бойченко М. К. \\ аспірантка кафедри теорії, практики та перекладу англійської мови \\ Національний технічний університет Украӥни \\ «Київський політехнічний інститут імені Ігоря Сікорського» \\ просп. Перемоги, 37, Київ, Україна \\ orcid.org/0000-0001-6100-4855 \\ boychenko515@gmail.com
}

\author{
Ключові слова: харизматична \\ особистість, вербально- \\ графічна модель, харизма, \\ харизматичні ознаки, \\ комунікація, механізм.
}

Стаття містить обгрунтування вербально-графічної моделі механізму сприйняття аудиторією харизматичних ознак публічної особистості. Для реалізації мети дослідження автором запропоновано узагальнену класифікацію ознак формальних $\mathrm{i}$ неформальних особистостей публічних харизматичних лідерів. У процесі теоретичного пошуку було виявлено необхідність формування складу оптимального термінологічного інструментарію, покликаного забезпечити повноту й однозначність наукового опису феномену комунікативної поведінки публічної харизматичної особистості та механізму сприйняття аудиторією харизматичних ознак публічної особистості. У результаті аналізу пропонованих авторами з різних галузей (психології, соціології, лінгвістики) ознак харизматичної комунікації у статті було запропоновано поділ на цільові ознаки та засоби актуалізації цілей спілкування. 3 метою створення зазначеної вище моделі за результатами теоретичного пошуку у статті було систематизовано особистісні характеристики мовця, представника аудиторії, умови комунікації, що можуть впливати на сприйняття харизматичних ознак. Для уникнення розуміння харизми в широкому сенсі автор роботи надає своє визначення цього явища, що відповідає меті започаткованого міждисциплінарного дослідження. У роботі представлено вербально-графічну модель механізму сприйняття аудиторією харизматичних ознак публічної особистості, що була розроблена на основі піраміди сфер духовного буття індивіда О. Клименюка. Запропонована модель представляє зазначений механізм як взаємодію двох систем, харизматичного мовця і реципієнта, який має певний культурний рівень, у навколишньому середовищі (конкретні умови комунікації). Ця модель обгрунтовує процес вибору оптимальних вербальних i невербальних засобів комунікації для здійснення максимального харизматичного впливу на реципієнта. Вказано на перспективність використання моделі в майбутніх міждисциплінарних дослідженнях здійснення сугестивного впливу лідера-мовця на аудиторію. 


\title{
MECHANISM OF PERCEPTION OF A PUBLIC FIGURE'S CHARISMATIC CHARACTERISTICS BY THE AUDIENCE
}

\author{
Boichenko M. K. \\ Postgraduate Student at the Department of Theory, \\ Practice and Translation of English \\ National Technical University of Ukraine \\ "Igor Sikorsky Kyiv Polytechnic Institute" \\ Peremohy ave., 37, Kyiv, Ukraine \\ orcid.org/0000-0001-6100-4855 \\ boychenko515@gmail.com
}

Key words: charismatic personality, verbal-and-graphic model, charisma, charismatic characteristics, communication, mechanism.
The paper provides rationale for the verbal-and-graphic model of the mechanism of perception of a public figure's charismatic characteristics by the audience. To fulfill the research aim, the author provides a generalized classification of personal traits of formal and informal charismatic public leaders. In the course of theoretical research, there has arisen the need to form optimal terminological instrumentarium, suitable for a complete comprehensive and conclusive scientific description of the phenomenon of charismatic public figures' communicative behaviour and the mechanism of perception of a public figure's charismatic characteristics by the audience. As a result of the analysis of charismatic communication features described by the authors from various areas of science (psychology, sociology, linguistics), the paper provides their division into principal features as well as the means of communicative purpose actualization. In order to create the abovementioned model, personal characteristics of a speaker, audience members and communication conditions, able to influence the perception of charismatic characteristics, have been systematized. To avoid a broad definition of charisma, the author offers their own definition of the phenomenon, serving the purpose of this interdisciplinary research. The article presents a verbal-and-graphic model of the mechanism of perception of a public figure's charismatic characteristics by the audience, developed on the basis of the Klymenyuk's pyramid of the person's spiritual being. The model presents the abovementioned mechanism as an interaction of two systems (a charismatic speaker and a recipient with a certain cultural level) in a specific environment (specific communication conditions). This model substantiates the process of choosing optimal verbal and non-verbal means of communication to exert charismatic influence on a recipient to the maximum extent. The author also outlines prospects of a further use of the model in interdisciplinary research of a leader speaker's subliminal influence on the audience.
Постановка проблеми. У результаті проведення аналізу наявних у лінгвістиці, психології й інших гуманітарних науках праць, спрямованих на визначення ознак публічної харизматичної особистості, неважко переконатися в тому, що, 3 одного боку, публічними лідерами можуть бути представники різноманітних професій, громадські, культурні та релігійні діячі тощо [9; 12; 28]; спілкування 3 аудиторією відбувається в різних комунікативних обставинах [25]; щодо аудиторії публічні харизматичні мовці можуть відрізнятися за соціальним статусом; різні типи публічного дискурсу реалізуються зазвичай за відмінними цілями на підставі використання відповідних засобів комунікативного впливу [25]; до засобів комунікативного впливу на аудиторію прийнято відносити лінгвальні (лексичні, синтаксичні, стилістичні тощо) засоби [1] і позалінгвальні (жести, міміка, одяг, погляд, постава або культурні знаки, певні коди, сигнали тощо) [14]; важливими ознаками харизматичного публічного мовця вважаються емоційність (емоційне піднесення, варіювання ступеня емоційного збудження, здатність емоційного апелювання до аудиторії тощо) та раціональність (правильна локалізація акцентів, здатність переконувати у правильності свого 
бачення, логічний аналіз ситуації, передбачення наслідків тощо) [13; 16; 24].

3 іншого боку, у згаданих вище джерелах зазначається, що на особливості сприйняття аудиторією харизматичних ознак публічної особистості впливають такі чинники: ситуація спілкування, культурний контекст комунікації, тема спілкування, емоційний стан аудиторії, ступінь однорідності аудиторії, соціальний статус, культурний рівень та гендерна приналежність харизматичного мовця, вік, раса харизматика, ораторська компетенція публічного харизматичного мовця тощо.

На жаль, автори багатьох описів особливостей перебігу публічної комунікації харизматичних мовців вельми довільно оперують науковою термінологією, зокрема вживають під час викладу ознак, характеристик, назв елементів публічної комунікації неадекватні за ієрархічним рівнем терміни. Окрім того, в аналізованих нами працях в обсязі системного опису механізму публічної комунікації політичних лідерів має місце зміщення понять, що стосуються стратегій, тактик, методів і засобів актуалізації промов харизматичними особистостями.

У ситуації, що склалася, виникає актуальність вирішення питання формування складу оптимального термінологічного інструментарію, покликаного забезпечити повноту й однозначність наукового опису феномену комунікативної поведінки публічної харизматичної особистості та механізму сприйняття аудиторією іiі харизматичних ознак.

Мета і завдання статті. Тому метою започаткованого нами теоретичного пошуку було обгрунтування оптимальних комплексів провідних ознак публічного харизматичного мовця та формування вербально-графічної моделі механізму сприйняття аудиторією харизми його особистості.

За основу наукових дій, спрямованих на досягнення поставленої мети, було прийнято таку послідовність методологічних процедур і пов'язаних із ними міркувань, що відображають завдання нашого пошуку. По-перше, нами було чітко усвідомлено, що для підвищення інформаційно-інтерпретаційного потенціалу викладу проблеми, що розглядається, процес харизматичної публічної комунікації доцільно представити у вигляді системної вербально-графічної моделі. Ми розуміли, що 3 погляду специфіки суб'єкт-об'єктної взаємодії загальний процес харизматичної публічної комунікації раціонально інтерпретувати вербально-графічною моделлю надсистеми, що складається із двох відповідно автономних систем (харизматичний мовець і його аудиторія), когнітивна взаємодія яких відбувається вербальними і позавербальними засобами спілкування в навколишньому середовищі, що охоплює конкретні умови спілкування. По-друге, важливою умовою такого моделювання, як показано вище, мають бути попередній аналіз та систематизація понять термінологічного апарату, якими варто описувати явища, що нами розглядаються. По-третє, треба зважати на те, що, будучи природно позиченими 3 різних галузей наукового знання, поняття, про які йдеться, набувають натепер статусу міждисциплінарних, отже, за цілком об'єктивних обставин $\epsilon$ в багатьох випадках неконвенціональними.

Предмет і об'єкт дослідження. Об'єктом нашого дослідження $\epsilon$ механізм харизматичної комунікації, а предметами виступають ознаки публічного харизматичного мовця та взаємодія елементів харизматичного спілкування.

Виклад основного матеріалу дослідження. В обсязі аналізу, спрямованого на вирішення зазначених вище питань, нами встановлено, що загальносоціальні ознаки публічних харизматичних особистостей (тобто комунікативних лідерів у широкому розумінні - М. Б.) варто обмежити їх конкретною сукупністю, викладеною в таблиці 1.

Таблиця 1

Узагальнена класифікація ознак формальних і неформальних особистостей публічних харизматичних лідерів

\begin{tabular}{|c|c|}
\hline Формальні лідери & Неформальні лідери \\
\hline - політичні; & - актори; \\
\hline - релігійні; & - співаки; \\
\hline - корпоративні; & - блогери; \\
\hline - інституціональні; & - письменники; \\
\hline - громадські. & - журналісти*. \\
\hline
\end{tabular}

*журналісти можуть виражати і просувати власну думку, наприклад в авторських програмах чи власних колонках, або ж бути ретрансляторами поглядів окремої медійної групи.

Зрозуміло, що ця класифікація охоплює лише термінологію верхнього рівня класифікації професійних ознак харизматичних лідерів, оскільки в разі конкретизації може йтися про керівників ідеологічних, громадських, екологічних організацій і об'єднань, керівників політичних угруповань, релігійних рухів, професійних об'єднань, груп, сект, корпорацій, підприємств тощо.

У попередній праці ми показали, що за частотністю згадувань як основні найбільш загальні ознаки на позначення харизматичної особистості публічного мовця в міждисциплінарних дослідженнях уживаються такі абстрактні поняття, як: інтелект, впевненість, заповзятість, натхненність, комунікабельність, домінантність, нариисизм, візіонерство. Варто підкреслити, що ці міждисциплінарні за сутністю поняття стосуються ознак харизматичних якостей особистості мовця та конвенціалізовані історично. Проте в різних 
галузях наукового знання (соціологічне, психологічне, лінгвістичне тощо), залежно від спрямованості цілей досліджень, щонайменше постає необхідність у використанні більш конкретних ознак, що входять до складу цих понять.

За цих обставин ми набуваємо підстав стверджувати, що провідними найзагальнішими ознаками харизми мовця варто вважати інтелект, упевненість, заповзятість, натхненність, комунікабельність, домінантність, нарцисизм, візіонерство.

Оскільки дослідник має можливість описувати ознаки комунікативної поведінки харизматичного лідера лише на підставі об’єктивно статистично опрацьованих думок представників аудиторії, то для побудови шуканої системної моделі механізму сприйняття представниками аудиторії харизматичних ознак публічної особистості $є$ сенс їх поділу на цільові ознаки й ознаки засобів актуалізації цілей спілкування.

За таких умов цільові ознаки харизматичної комунікації традиційно варто диференціювати на стратегіï, тактики, методи, способи, прийоми, засоби. У свою чергу, ознаки засобів реалізації комунікативних намірів лідерів, які здійснюють вплив на аудиторію, доцільно поділяти на вербальні й невербальні.

Щодо ознак, здатних викликати у представників аудиторії відчуття харизматичності комуніканта, то за різними джерелами їх детермінують поняттями на кшталт «елемент», «атрибут», «компонент», «засіб» комунікації. Це пов' язано насамперед із розмаїттям цілей досліджень та використанням як теоретичного підгрунтя переважного впливу концепцій структурного або функціонального підходів. Тому, зважаючи на чітко визначений у праці [1] функціонально-алгоритмічний ланцюжок ознак (стратегія $\rightarrow$ тактика $\rightarrow$ метод $\rightarrow$ спосіб $\rightarrow$ прийом $\rightarrow$ засіб), під час подальшого розгляду характеристик харизматичності лідера ми будемо акцентувати увагу на функціональному призначенні кожної з них.

Так, у праці [10] до елементів комунікації автори відносять: 1) вербальні (уживання історій, метафор, порівнянь, риторичних запитань, трискладових списків, цілісність, вираження спільних емоцій і впевненості в комунікації, реалізація високих очікувань); 2) невербальні (використання міміки, жестів і енергійного голосу, паузи, шепотіння, підвищена гучність, посмішки, зоровий контакт).

У публікації Schmid (1985 р.) [16] як ознаки харизматика розглядаються такі компоненти комунікації, як: авторитарність, емпатія, ентузіазм, символізм, повтори, швидке мовлення. Але, на наш погляд, авторитарність, емпатію й ентузіазм точніше вважати ознаками або характерис- тиками харизматичної особистості. Символізм та повтори, за наведеною вище класифікацією, варто сприймати як вербальні засоби спілкування. Подібним чином швидке мовлення прийнято відносити до невербальних засобів комунікації.

У міркуваннях про харизматичну комунікацію K. Klein, R. House [22] ідеться про елементи, що їх використовують мовці (вираження ідеологічних цілей, високих сподівань і впевненості в послідовниках, підкреслення символічних і емоційних аспектів завдання/мети, вираження візіонерської місії, апеляція до колективного і до колективної ідентичності (а не до особистісних інтересів послідовника), прийняття на себе особистісних ризиків і жертв) [22, с. 184]. Як бачимо, ці ознаки радше віднести до цільових.

Цікавим є спостереження авторів S. Holladay, W. Coombs (1993 р.) про те, що подача повідомлення важливіша навіть за його зміст. Автори вважають, що механізм харизматичної комунікації може буде розділений на два компоненти, як-от: 1) зміст повідомлення лідера; 2) презентація, подача цього повідомлення (зоровий контакт, голосова варіативність, міміка, жести) [14, с. 376]. Оскільки подача повідомлення $є$ комплексним засобом реалізації комунікативного впливу, то зміст та засоби його транслювання радше варто розглядати як дві його складові частини.

У статті Howel \& Frost (1989 р.) виокремлено такі атрибути комунікації, як захоплюючий і привабливий тон голосу мовця, ходіння взад - уперед і сидіння, нахиляння вперед, регулювання темпу мовлення, прямий зоровий контакт, жвавий вираз обличчя [16]. На нашу думку, усі ці атрибути є радше особливостями невербальної поведінки харизматичного мовця.

Автори ще однієї праці (B. Shamir, R. House, M. Arthur, 1993 р.) також розглядають харизматику комунікації шляхом виокремлення таких іiі атрибутів, як: підкреслення символічної поведінки лідера, візіонерські й надихаючі повідомлення, невербальна комунікація, звернення до ідеологічних цінностей, інтелектуальна стимуляція послідовників лідером, вираження впевненості в собі і послідовниках, очікування лідером самопожертви послідовників і дій із власної ініціативи [16]. Проте, звертаючись до наведеної вище класифікації елементів харизматичної комунікації, неважко переконатися в тому, що інтелектуальна стимуляція послідовників лідером може вважатися прийомом, а всі інші атрибути стосуються змісту повідомлення мовця.

Ще одна група авторів (Frese, Beimel \& Scnoeborn, 2003 р.) описують харизматичну комунікацію через такі іiі атрибути, як: зоровий контакт, жести, варіативність швидкості та гучності мовлення, орієнтація на аудиторію, повтори візіі, 
пояснення важливості візії, апеляція до цінностей, використання метафор, збільшення впевненості у власних силах групи, емоційна апеляція, позитивні твердження, використання форми «ми» [16]. Убачається, що запропоновані атрибути можуть бути поділені на вербальні засоби нижчого ієрархічного рівня (прийоми і засоби) і засоби невербальної комунікації.

Автор статті [27] характеризує досліджувану комунікацію, виокремлює такі іiі атрибути, як: візіонерські твердження, автобіографія, метафори, аналогії, підвищення впевненості у власних силах, сторітеллінг, твердження на основі суджень про цінності, підвищення очікувань. Спираючись на обрану нами класифікацію, пропоновані атрибути варто класифікувати як вербальні засоби, а саме прийоми й засоби.

Дещо інші ознаки виокремлено у праці Levine (2009 р.), який розглядає харизматичну комунікацію через іiі атрибути: мовець може бути емпатичний щодо інших, знає, коли треба слухати, а коли говорити, урівноважений, умілий оратор, підтримує зоровий контакт під час комунікації, заспокоює інших, повний ентузіазму, наполегливий, комфортно почувається під час публічного мовлення, розуміє, чого хочуть люди, часто посміхається, просить інших поширювати ідеї, просить людей поділитися їхніми думками [16]. Запропоновані вище атрибути-ознаки являють собою, на наш погляд, три групи окремих елементів комунікації, як-от: вербальні засоби, невербальні засоби i характеристики чи ознаки самої харизматичної особистості мовця.

Своєрідні ознаки розглянуто у праці Н. Tan $[26$, с. 3], автор якої препарує риторичний зміст публічних харизматичних лідерів та звертає увагу на такі елементи, як уміння мовця надавати силу для змін, звертатися до історії, наголошувати на впевненості послідовників у власних силах, акцентувати на колективній ідентичності, виражати впевненість, підсилювати обрані цінності, зазначати минулі успіхи, наголошувати на схожості $з$ послідовниками. Усі зазначені елементи впливу варто, на наш погляд, розглядати як вербальні прийоми комунікації.

У результаті узагальнення результатів огляду наявної в лінгвістичних, соціологічних і психологічних працях термінології на позначення ознак харизматичної комунікації неважко дійти висновку, що всі дослідники виокремлюють переважно вербальні, невербальні засоби й ознаки особистості самого мовця. Саме таку диференціацію ознак харизматичності мовця доцільно, на наш погляд, закладати в основу їх наукового опису як провідних чинників, здатних здійснювати більш або менш суттєвий вплив на виникнення відчуття харизматичної особистості лідера у слухачів.
Щодо безпосередніх уявлень дослідників про механізм сприйняття аудиторією харизматичних ознак публічної особистості, то ми змушені звернути увагу на таке. Оскільки зазначений механізм $€$ по суті об'єктом когнітивного міждисциплінарного дослідження, то немає нічого дивного в тому, що, зважаючи на відносно невеликий вік розвитку цієї галузі наукового знання, шукану нами конкретну модель досі не створено.

Проте пошуки в напрямі вирішення цієї проблеми вже розпочато. Так, на думку Н. Петлюченко, деякі дослідники стверджують, що сприйняття харизматичності лідера зумовлюється екстраординарними зовнішніми умовами (криза, революція) $[5$, с. 396].

Також є думка, прихильники якої зазначають, що криза чи революція - досить рідкісні випадки, тому харизматична особистість може 3'являтися просто в ситуаціях, що змушують людей відчувати невпевненість, невизначеність, коли вони не мають чіткого бачення цілей, стратегій, у яких постає необхідність у моральному лідерстві й емоційній включеності в ситуацію [22, с. 186].

Убачається за необхідне звернути також увагу на ознаки, що, на думку дослідників, виокремлюють харизматичну комунікацію з-поміж інших видів спілкування лідерів 3 їхньою аудиторією: установлення більш глибокого емоційного зв' язку між лідером і послідовниками, ніж в інших типах лідерства, і фокусування на ньому [24, с. 6; 16, с. 73]; акцентування лідером уваги на тому, що послідовники є частиною особливого соціального колективного цілого; надавання харизматичним лідером аудиторії особливої мети, що дає представникові такої аудиторії розуміння, що він $€$ непересічною особистістю [24, с. 7].

Загалом за результатами експериментальних i теоретичних досліджень у галузі лінгвістики, психології та соціології науковцями було описано особистісні характеристики мовця та представника аудиторії, а також загальні умови комунікації, що впливають на сприйняття аудиторією мовця як харизматичного. У їхніх описах наголошується на такому:

- однією 3 найважливіших загальних умов комунікації є збіг культурних норм мовця і реципієнта (лідера будуть сприймати як більш харизматичного, якщо він буде відповідати культурним очікуванням послідовників) $[6$, с. $34 ; 18$, с. 2 ; 19 , с. $15 ; 16$, с. $32 ; 15]$;

- важливими особистісними характеристиками представника аудиторії постають його стать, paca, соціально-економічний статус і вік (комплекс цих характеристик пояснює відмінності у способі декодування невербальної поведінки й ідентифікацію мовця як більш чи менш харизматичного) $[11$, с. $34 ; 20$, с. $30-34]$; 
- на сприйняття мовця як харизматика, поряд iз психологічними ознаками, впливають його гендер (спікери-чоловіки сприймаються як більш харизматичні, ніж жінки, незважаючи на те, що характеристики мовлення і невербальні засоби мовців обох статей є однаковими) [21] і зовнішній вигляд (включає декілька компонентів, серед яких привабливість, одяг і доглянутість);

- будь-яка потенційна суперечність між вербальним повідомленням лідера та зовнішнім виглядом є серйозною перешкодою для ефективного спілкування [23, с. 16].

3 викладеного очевидно, що проаналізована вище система ознак та методологічних умов щодо опису особливостей перебігу процесу комунікації є цілком достатньою для наукового опису когнітивної моделі інтерпретації механізму сприйняття аудиторією харизматичних ознак публічної особистості.

За результатами аналізу в межах опису зазначеного механізму під харизмою 3 функціонального погляду доцільно розуміти систему уявлень, що виникають у свідомості слухачів на підставі сприйняття тих комплексів лінгвальних і позалінгвальних засобів комунікації, якими послуговується мовець, а також його зовнішніх, психологічних, фізіологічних та соціальних ознак, які свідчать про здатність мовця задовольнити назрілі соціальні потреби або запити аудиторії.

Звернемося безпосередньо до ступеня розробленості проблеми моделювання механізму сприйняття аудиторією харизматичних ознак публічної особистості та зауважимо таке. Мабуть, однією 3 найповніших вітчизняних праць, покликаних висвітлювати питання, що прямо стосуються харизматичної мовної особистості, є монографія Н. Петлюченко [6]. У зв'язку із цим зазначимо, що, викладаючи сутність феномену приписування референтною групою лідерові певних харизматичних властивостей у найбільш загальних рисах, авторка цієї праці наводить [5, с. 97-106] загальну інтерпретаційно-логічну схему харизматичної комунікації. Перебіг процесу формування харизматичних уявлень поділено нею на два етапи: первинного та вторинного приписування харизматичних властивостей мовцю. Розгляд проблеми набуття харизми авторкою побудовано за таким логічним алгоритмом: адресант (політичний лідер), адресат (народ) і послання. У іï праці приділено також увагу національним архетипам енергетики харизматичного політичного лідера.

На жаль, наведені в монографії [6, с. 92-99] схеми-моделі харизматичної комунікації та механізму харизматичного мовленнєвого впливу мають високий ступінь загальності, отже, не можуть бути безпосередньо використані для досягнення мети нашого пошуку. Це вкотре підтверджує актуальність обгрунтування шуканої нами когнітивної моделі інтерпретації механізму сприйняття аудиторією харизматичних ознак публічної особистості, результати якого втілено нами у графічному образі, відтвореному на рис. 1 .

Згідно 3 визначеними вище методологічними умовами, представлену модель побудовано у вигляді надсистеми, що складається із двох автономних систем (харизматичний мовець i його аудиторія).

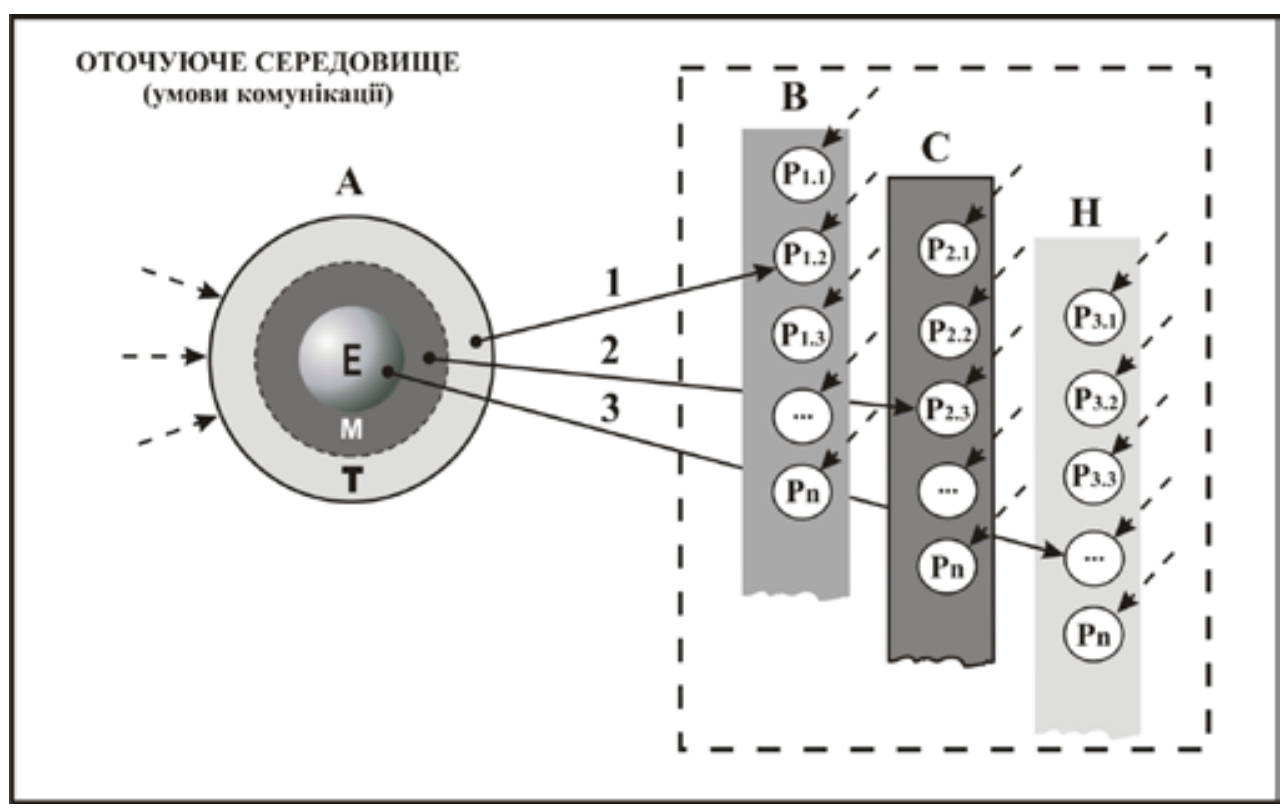

Рис. 1. Когнітивна інтерпретаційна модель механізму сприйняття аудиторією харизматичних ознак публічної особистості 
Перша система позначена на моделі літерою (A). Ї̈і графічним образом інтерпретовано сфери духовного буття публічного харизматичного мовця, який під час комунікації, що нами розглядається, виконує роль адресата. Змістове насичення елементів та назва сфер цієї системи є тотожними їх трактуванню у відомій когнітивістам піраміді О. Клименюка [3]. Нагадаємо, відповідно до змістового насичення елементів цієї піраміди, умовно послідовний перебіг когнітивних процесів духовного буття мовця відбувається в таких сферах: екзистенційній, ментальній, трансцендентній ісфері свідомого. За цих умов 3 погляду системного підходу ми й поділяємо систему на три відповідні підсистеми: екзистенційну, ментальну, трансцендентну [8].

Тому в центрі побудованої таким чином системи (А) на моделі нами зображено сферу екзистенційного буття харизматичного мовця (Е), яку охоплено відповідно сферами його ментального (М) та трансцендентного (Т) буття. Сферу свідомого інтерпретовано у вигляді окружності, що виконує водночас й роль оболонки цієї системи.

У подальшому викладі ми, поділяючи бачення автора піраміди [3, с. 205-213], будемо виходити, по-перше, $з$ того, що рушійною силою всіх когнітивних процесів мислемовлення та миследій, які протікають у згаданих сферах психіки, є психофізіологічна енергія особистості харизматичного мовця. По-друге, будемо дотримуватися розуміння того, що екзистенційне буття людини, яке здійснює свій перебіг у сфері позасвідомого, грунтується суто на іiї емоційному мисленні, ментальне буття відбувається завдяки емо-раціональному мисленню, трансцендентне - оперує раціональним мисленням, а у сфері свідомого превалює логіко-діалектичне мислення.

Ми спираємося на концептуальне підгрунтя праць [3, с. 207-213; 8] та поділяємо думку автора про те, що у процесі комунікації харизматичний лідер здатен здійснювати інформаційний вплив на кожного представника аудиторії у трьох сферах його духовного буття: екзистенційній, ментальній, трансцендентній, а також на рівні свідомості, тобто охоплювати позасвідоме (екзистенційна сфера), підсвідоме (ментальна та трансцендентна сфери) і свідомість.

Нагадаємо, що за таким баченням під терміном екзистенційний варто [3, с. 207-211] розуміти все, що стосується унікальної неповторності внутрішнього буття людини, відчуття нею своєї приналежності до вищого та не може бути викладеним мовою понять. Це пов'язано 3 тим, що екзистенційне буття індивіда здійснює свій перебіг на рівні його позасвідомості, грунтується на емоційному мисленні. Під поняття «ментальний» підпадає така уявна цілісність, що спрямована на віддзеркалення індивідом навколишньої реальності. Ментальні уявлення зумовлені колективною свідомістю, оскільки набуваються людиною суто у процесах соціалізації. На відміну від екзистенційного, ментальне буття індивіда розгортається в його психіці на рівні підсвідомості та базується на емоційно-раціональному мисленні. На цьому рівні здійснюють свій перебіг і когнітивні процеси трансцендентного буття, в основі якого домінує креативне раціональне мислення.

Саме завдяки цій особливості функціонування психіки людини залежно від рівня культури реципієнтів ( $\mathrm{H}$ - низького, $\mathrm{C}$ - середнього чи В - високого) послання мовця-харизматика набуває здатності впливати на окремі сфери духовного буття (а отже, і на перебіг мислення) будь-якого представника аудиторії.

Наведена на рис. 1 друга система, що інтерпретує аудиторію (див. штриховий прямокутник), також складається із трьох підсистем (колонок), які позначено відповідно літерами В, C, Н. Перша ліва колонка (В) символізує групу слухачів або реципі$\epsilon$ нтів $\left(\mathrm{P}_{1.1}, \mathrm{P}_{1.2}, \mathrm{P}_{1.3}, \ldots \mathrm{Pn}\right)$, що мають високий культурній рівень. Колонка (С) охоплює реципієнтів середнього культурного рівня $\left(\mathrm{P}_{2.1}, \mathrm{P}_{2.2}, \mathrm{P}_{2.3}, \ldots \mathrm{Pn}\right)$, а колонка $(\mathrm{H})$ - реципієнтів низького культурного рівня $\left(\mathrm{P}_{3.1}, \mathrm{P}_{3.2}, \mathrm{P}_{3.3}, \ldots \mathrm{Pn}\right)$. Оболонку цієї системи зображено штриховим прямокутником.

3 моделі видно, що взаємодія цих двох систем відбувається в навколишньому середовищі, роль якого відіграють реальні умови комунікації харизматика 3 аудиторією. Нагадаємо, що саме особливості та зміни умов комунікації (час, місце, тип комунікації, ідеологічна однорідність аудиторії, культурний аспект тощо) породжують такі комплекси чинників, які здатні суттєво впливати (стимулювати/табуювати) на використання мовцем тих або тих засобів спілкування, чи змушувати слухача правильно/неправильно декодувати зміст послання мовця. Комплекси зазначених чинників зображено на моделі штриховими стрілками.

Суцільними стрілками (1, 2 та 3) на моделі інтерпретовано вербальну й невербальну інформацію, що у процесі комунікації, будучи породженою у сферах екзистенційного, ментального або трансцендентного буття мовця, здатна знаходити відповідний відгук у психіці реципієнтів - представників аудиторії певного мовно-культурного рівня, отже, поставати панівним чинником у створенні ним харизматичних уявлень щодо мовця.

Узагальнення результатів низки лінгвокогнітивних досліджень свідчить, що залежно від рівня культури слухачів (низький, середній чи високий) мовець-харизматик зазвичай апелює до певних сфер буття (отже, і типів мислення) кожного такого реципієнта - екзистенційної, 
ментальної або трансцендентної відповідно. Так, у працях $[24$, с. $6 ; 16$, с. 73$]$ показано, що харизматичні мовці спираються передусім на формування емоційного зв'язку з послідовниками (див. стрілку 3 на моделі), отже, апелюють до емоційного мислення реципієнтів, орієнтуючись на базовий низький рівень їхньої культури. Мовою сучасної науки, харизматичний лідер, який звертається до аудиторії середнього культурного рівня, має апелювати до емоційно-раціонального мислення аудиторії, що вимагає використання більш складних концептів та врахування не лише емоційного зв'язку 3 аудиторією. Не зайвим буде звернути увагу і на те, що для здійснення комунікативного впливу на аудиторію високого культурного рівня мовець-харизматик має спиратися на раціональні концепти, що відповідають меті й умовам комунікації. Зафіксовано [22, с. 187] також той факт, що деякі харизматичні особистості можуть сприйматися як такі лише в невеликих групах, навіть окремими представниками однієї групи, тобто сприйняття харизми не завжди є однорідним.

Звідси випливає, що кількісний показник сприйняття представниками аудиторії будь-якого мовця як харизматичного залежить від його здатності визначати культурний рівень своєї аудитоpiï, брати до уваги особистісні характеристики іiі типового представника (вік, стать, соціальний статус тощо), аналізувати умови комунікації, зокрема головний аспект - культурний контекст. 3 урахуванням зазначеного харизматичний мовець має обрати відповідні вербальні (прийоми, методи тощо) та невербальні (одяг, жести, міміка) засоби, що дозволять йому максимально повно реалізувати мету комунікації та здійснити необхідний вплив на аудиторію. Водночас дослідникові варто розуміти, що всі розглянуті вище невербальні ознаки не діють окремо на сприйняття лідера-мовця як харизматичного, оскільки цей процес зумовлюється впливом на слухача саме комплексів цих невербальних чинників-ознак, що стохастично взаємодіють один 3 одним та 3 іншими мовленнєво-лінгвістичними, психологічними, культурно-соціальними i фізіологічними ознаками, а також із їх відповідними комплексами.

За допомогою інтерпретаційного потенціалу сформованої таким чином моделі ми отримуємо можливість наукового опису механізму сприйняття аудиторією харизматичних ознак публічної особистості. Для поглиблення уявлень про механізм сприйняття реципієнтами харизматичних ознак мовця нагадаємо, відповідно до джерела [4], таке:

- роль інстинктів у комунікативній поведінці людини полягає насамперед у тому, що вони слугують джерелом пускових імпульсів, збуджуючих певні емоції, які протягом свого перебігу гене- рують психофізіологічну енергію стохастичного саморозвитку процесів мислемовлення та миследій індивіда під час продукування або декодування ним інформації;

- запуск інстинктивної реакції у формі нейрофізіологічного збудження починається 3 електрохімічного активування енергії концепту або концептів одного чи трьох основних інстинктів (подовження роду, пізнання, самовиживання), які зберігаються в нейронах пам'яті людини;

- результати перебігу у психіці індивіда процесів мислемовлення та миследій, що пов'язані зі складною суперечливою енергетичною взаємодією інстинктів, емоцій, почуттів, емоційних і ментальних табу, віддзеркалюються в актуалізованих ним лінгвальних і позалінгвальних засобах комунікативної поведінки.

Викладене, з урахуванням низки провідних концептуальних положень фундаментальних праць [2; 3], надає підстави для такого тлумачення механізму сприйняття аудиторією харизматичних ознак публічної особистості. За нашим баченням, результатом синергетичного саморозвитку процесів мислемовлення та миследій у сфері духовного буття (див. систему А на рис. 1) харизматика стає його мовленнєва поведінка, яка актуалізується за допомогою певних комплексів лінгвальних і позалінгвальних засобів комунікації з аудиторією. До складу таких комплексів можуть входити і засоби, які породжуються в різних сферах (E, M та T) буття мовця, і в одній із них. За природою походження ці засоби можуть також бути різними: вербальні (лексичні, стилістичні тощо) і невербальні (фонетичні, мімічні, жестові тощо).

Сформоване таким чином звернення мовця-харизматика сприймається кожним представником аудиторії (див., напр., $\mathrm{P}_{1.2}$ та $\mathrm{P}_{2.3}$ ) індивідуально, оскільки його сприйняття залежить від багатьох чинників: рівня культури реципієнта, ступеня збігу мовних культур мовця й адресанта, ступеня офіційності комунікації, потреб, духовних запитів і очікувань реципієнта, співвіднесення соціальних та рольових статусів мовця і реципієнта, співвідношення віку, статі мовця і слухача, обраних мовцем стратегії, тактик, способів, прийомів і засобів комунікації, статуту та зовнішнього вигляду мовця, темпераментів і емоційних станів мовця і слухача під час комунікації, емоційної привабливості та логічності аргументації мовця, інтровертної/екстравертної мовленнєвої поведінки мовця, емоційних і соціально набутих табу психіки реципієнта, його фізичного самопочуття тощо.

Iз плином історичного часу зазначені особливості набули статусу чинників, результат взаємодії яких у психології, лінгвістики, соціології й інших науках прийнято співвідносити з особливостями і наслідками перебігу досліджуваних 
різновидів комунікації. Звідси випливає доцільність їх використання в ролі чинників під час проведення більш широких міждисциплінарних наукових пошуків, об'єктом яких стає комунікація в iï широкому розумінні. Саме на такому розумінні грунтується графічний образ моделі другої системи, яка символізує структуру аудиторії мовця харизматика.

У цій моделі суцільними окружностями позначено кожного слухача, якого за критерієм його культурного рівня віднесено до тієї чи тієї групи представників аудиторії (B, C, Н). Під змістовим насиченням графічного образу будь-якого кола другої системи, що обмежено в нашій моделі суцільними окружностями, варто, за аналогією до системи (А), розуміти сферу духовного буття слухача $з$ їі відповідним поділом на вже згадувані автономні екзистенційну, ментальну та трансцендентну сфери.

Окрім того, необхідно розуміти, що під час комунікації разом і водночас із вербальною інформацією у свідомість, передсвідомість та позасвідомість кожного представника аудиторії п’ятьма каналамами його перцептивної системи поступає (див. штрихові стрілки на рис. 1) інша (додаткова) інформація, яка відповідно до його культурного рівня $(\mathrm{B}, \mathrm{C}, \mathrm{H})$ стає зазвичай основною (див стрілки $1,2,3)$ у сприйнятті або несприйнятті мовця як харизматичної особистості.

Енергетична взаємодія збуджуваних нейронів, що зберігають у пам'яті мовця розмаїття концептів таких засобів, приводить до неминучого домінування енергетичного потенціалу лише окремих концептів, породжених у кожній зі сфер (E, M i T). Таки різні за природою та сферою походження концепти агрегатуються у складні енергетично насичені ї комплекси, що матеріалізуються в кінцевих формах засобів актуалізації змісту повідомлень, які харизматичний мовець транслює аудиторії в обсязі свого послання (див. на моделі стрілки 1,2 та 3).

Матеріалізація кожного окремого комплексу концептів - засобів комунікації відбувається лише тоді, коли він, подавляючи інші наявні в пам'яті мовця альтернативи подібних комплексів, набуває енергетичного потенціалу, що перевищує, отже, пригнічує сумарний енергетичний потенціал табу, які завжди наявні в емоційній, ментальній і трансцендентній сферах психіки будь-якої людини. Зазвичай процеси матеріалізації результатів мислемовлення та миследій харизматика контролюються його свідомістю у співвіднесенні наявних табу з умовами комунікації, унаслідок чого концепти-засоби з низьким енергетично-прагматичним потенціалом не матеріалізуються і залишаються в його внутрішньому мовленні. Іноді під час збудження у психіці мовця потужних емо- ційних концептів табуювання актуалізації свідомістю ненормативних засобів комунікації стає неможливим. Матеріалізовані таким чином звернення харизматичного мовця і спрямовуються на представників аудиторії, тобто транслюються (стрілки 1, 2 та 3) від першої (А) до другої систем нашої моделі.

Звертаючись до особливостей перебігу когнітивних процесів сприйняття аудиторією харизматичних ознак публічної особистості, акцентуємо насамперед на такому. Мислення людини, як відомо [3, с. 147-168], є по суті полілектичним. Процес його саморозвитку відбувається завдяки практично миттєвій суперечливій взаємодії потенціалів психофізіологічної енергії певної множини протилежних за змістом та різних за природою походження концептів. Інакше кажучи, полілектичний саморозвиток мислення $\epsilon$ суто енергетичним процесом. Проте декодування та вербалізація його результатів потребують від людини навичок діалектичної логіки, засобами якої протягом набуття комунікативного й життєвого досвіду формується і зберігається в іiї пам'яті зміст різних за природою походження концептів, що набули за результатами полілектичного мислення досить високого енергетичного потенціалу. Простіше кажучи, свідомість людини грунтується суто на діалектичному мисленні.

Висновки та перспективи подальших розробок. Узагальнення результатів проведеного нами теоретичного пошуку дозволяє стверджувати таке.

Сформована вище вербально-графічна модель здатна виконувати функцію провідного методологічного інструментарію системного міждисциплінарного наукового опису феномену, чинників, умов і результатів продукування лідером суспільної думки, сприйняття його представниками аудиторії як харизматичного мовця.

Результати визначення та систематизації понять, якими позначаються провідні ознаки харизматичного мовця, можуть, на наш погляд, слугувати надійним джерелом та вихідним кроком у напрямі подальшої природної конвенціалізації міждисциплінарної наукової термінології.

Перспективність практичного використання інтерпретаційної моделі механізму сприйняття аудиторією харизматичних ознак публічної особистості полягає в тому, що вона дозволяє здійснювати концептуальне фокусування уваги дослідників когнітивістів лінгвістичної, психологічної, соціологічної й інших галузей гуманітарного наукового знання на виробленні уніфікованих міждисциплінарних уявлень про важливий комунікативний феномен сугестивного впливу лідера на послідовників. 


\section{ЛІТЕРАТУРА}

1. Калита А., Тараненко Л. Система целей и средств суггестивного воздействия в коммуникации. Вісник Київського національного лінгвістичного університету. Серія "Філологія». 2012. T. 15. № 2. C. 47-56. URL: http:// nbuv.gov.ua/UJRN/Vknlu_fil_2012_15_2_8.

2. Калита А. Энергетика речи : монография. Киев : Кафедра, 2016. 292 с.

3. Клименюк А. Знание, познание, когниция : монография. Тернополь, 2010. 304 с.

4. Клименюк А., Калита А. Энергетическая система и механизмы реализации когнитивных процессов. Вісник Харківського національного університету імені В.Н. Каразіна. Серія «Германістика та міжкультурна комунікаиія». Харків, 2012. № 1. С. 10-19.

5. Петлюченко Н. Модель харизматичної комунікації у німецькому та українському публічному дискурсі. Наукові праці Національного університету «Одеська юридична академія». 2012. T. 12. C. 392-401. URL: http://nbuv.gov.ua/ UJRN/Nponyua_2012_12_41.

6. Петлюченко Н. Харизматика : мовна особистість і дискурс : монографія. Одеса : Астропринт, 2009. 464 с

7. Стернин И. Введение в речевое воздействие. Воронеж, 2001. $266 \mathrm{c}$.

8. Тараненко Л. Пирамида Клименюка - универсальный методологический инструментарий когнитивистики. Актуальні питання іноземної філології : науковий журнал. Луцьк : Східноєвроп. нац. ун-т ім. Лесі Українки, 2019. № 11. C. 123-131.

9. Adair-Toteff C. Charisma, Social Aspects of. International Encyclopedia of the Social \& Behavioral Sciences / ed. J.D. Wright. Second Edition. Elsevier, 2015. P. 353-357.

10. Antonakis J., Fenley M., Liechti S. Learning charisma. Transform yourself into the person others want to follow. Harvard Business Review. 2012. Vol. 90 (6). P. 127-147.

11. Awamleh R. Towards A Model of Charismatic Non-Verbal Impression Management. International Business \& Economics Research Journal (IBER). 2011. Vol 2. № 7. P. 27-38.

12. Bensman J., Givant M. Charisma and Modernity: The Use and Abuse of a Concept. Social Research. 1975. Vol. 42 (4). P. 570-614.

13. Conger J. Charismatic and transformational leadership in organizations: An insider's perspective on these developing streams of research. Leadership Quarterly. 1999. Vol. 10. P. 145-179.

14. De Vries R., Bakker-Pieper A., Oostenveld W. Leadership = Communication? The Relations of Leaders' Communication Styles with Leadership Styles, Knowledge Sharing and Leadership
Outcomes. Journal of business and psychology. 2010. Vol. 25. P. 367-380.

15. The Perception of Charisma from Voice: A Cross-Cultural Study / F. D'Errico et al. Proceedings - 2013 : Humaine Association Conference on Affective Computing and Intelligent Interaction. ACII. 2013. P. 552-557.

16. Fabbi P. The effects of charismatic communication training on leader communication effectiveness. Doctoral dissertation / Olivet Nazarene University, 2013. 162 p.

17. Fragouli E. The dark-side of charisma and charismatic leadership. The Business and Management Review. 2018. Vol. 9. № 4. P. 298-307.

18. Gutnyk A., Niebuhr O., Gu W. Speaker Charisma Analyzed through the Cultural Lens. In 2021 12 th International Symposium on Chinese Spoken Language Processing (ISCSLP) IEEE. 2021. URL: https://findresearcher.sdu.dk:8443/ws/ files/182043942/ASpeaker_charisma_analyzed through the_cultural_lens.p.pdf (дата звернення: 03.10.2021).

19. A follower-centric perspective on charismatic leadership: An integrative review and agenda for future research / J. Harrison et al. Routledge International Handbook of Charisma. 2020. URL: https://hal.archives-ouvertes.fr/hal-03086811/ document (дата звернення: 03.10.2021).

20. Heracleous L., Klaering L.A. Charismatic Leadership and Rhetorical Competence: An Analysis of Steve Jobs's Rhetoric. Group \& Organization Management. 2014. Vol. 39. P. 131-161.

21. Influence of age, gender and sample duration on the charisma assessment of German speakers / O. Jokisch et al. In Studientexte zur Sprachkommunikation: Elektronische Sprachsignalverarbeitung. P. 224-231. URL: http://www.essv.de/ pdf/2018_224_231.pdf (дата звернення: 03.10.2021).

22. Klein K.J., House R.J. On fire: Charismatic leadership and levels of analysis. The Leadership Quarterly. 1995. Vol. 6 (2). P. 183-198.

23. Louekari L. Charismatic communication style in knowledge-intensive organizations. Master's thesis / Aalto University. School of Business, 2015. 60 p.

24. Riggio R., Riggio H. Social Psychology and Charismatic Leadership. Leadership at the crossroads: Social psychology and Leadership / Ed. D.R. Forsyth, C. Hoyt, G. Goethals. Praeger, 2008. P. 30-44.

25. Sandberg Y., Moreman C.M. Common Threads among Different Forms of Charismatic Leadership. Journal of Religion and Business Ethics. 2015. Vol. 3. Art.19. URL: https:// via.library.depaul.edu/jrbe/vol3/iss1/19.

26. Tan H.H., Wee G. The Role of Rhetoric Content in Charismatic Leadership: A Content Analysis of 
a Singaporean Leader's Speeches. International Journal of Organization Theory and Behavior. 2002. Vol. 5 (3/4). P. 317-342.

27. Towler A.J. Effects of charismatic influence training on attitudes, behavior, and performance. $\mathrm{Per}$ sonnel Psychology. 2003. Vol. 56 (2). P. 363-381.

28. Tucker R.C. Personality and Political Leadership. Political Science Quarterly. 1977. Vol. 92 (3). P. 383-393.

\section{REFERENCES}

1. Kalyta, A. \& Taranenko, L. (2012). Sistema tselei i sredstv suhhestsvnoho vozdeistviia $\mathrm{v}$ kommunykatsii [The system of aims and means of subliminal influence in communication]. Visnyk Kyivskoho natsionalnoho linhvistychnoho universytetu. Seriia.: Filolohiia. 15 (2), 47-56. URL: http://nbuv.gov.ua/UJRN/Vknlu_fil_2012_ 1528 .

2. Kalyta, A. Energetika rechi : monografiya [Speech energetics]. (2016). Kyiv, Kafedra.

3. Klimenyuk, A. (2010). Znanie, poznanie, kognicija [Knowledge, intellection, cognition]. Ternopol' : Pidruchniki i posibniki.

4. Klymenyuk A.V. \& Kalyta A.A. (2012) Energeticheskaya sistemai mehanizmyi realizatsii kognitivnyih protsessov [Energetic system and mechanisms of cognitive processes realization]. Visnyk Kharkivskoho natsionalnoho universytetu im. V.N. Karazina. Seriia "Hermanistyka ta mizhkulturna komunikatsiia”, № 1, 10-19.

5. Petlyuchenko N.V. (2012). Model kharyzmatychnoi komunikatsii u nimetskomu ta ukrainskomu publichnomu dyskursi [Model of charismatic communication in German and Ukrainian political discourse]. Naukovi pratsi Natsionalnoho universytetu "Odeska yurydychna akademiia", 12, 392-401. URL: http://nbuv.gov.ua/ UJRN/Nponyua_2012_12_41

6. Petlyuchenko N.V. (2009). Kharyzmatyka: movna osobystist i dyskurs: [monohrafiia] [Charismatics: Linguistics personality and discourse]. Odesa : Astroprynt.

7. Sternin I.A. (2001). Vvedenie v rechevoe vozdejstvie [Introduction to speech impact]. Voronezh : Kvarta.

8. Taranenko, L. (2019). Klymenyuk's pyramid as a universal methodological tool of cognitive studies. Aktualni pytannia inozemnoi filolohii: naukovyi zhurnal. Lutsk. 11, 123-131.

9. Adair-Toteff, C. (2015). Charisma, Social Aspects of. In James D. Wright (Ed.), International Encyclopedia of the Social \& Behavioral Sciences (Second Edition) (pp. 353-357). Elsevier. https:// doi.org/10.1016/B978-0-08-097086-8.32014-1.

10. Antonakis J, Fenley M, Liechti S. (2012) Learning charisma. Transform yourself into the person others want to follow. Harvard Business Review. 2012 Jun; 90 (6), 127-30, 147.

11. Awamleh, R. (2011). Towards A Model of CharismaticNon-Verbal Impression Management. International Business \& Economics Research Journal (IBER). 2 (7), 27-38. DOI: 10.19030/ iber.v2i7.3818.

12. Bensman, J., \& Givant, M. (1975). Charisma and Modernity: The Use and Abuse of a Concept. Social Research, 42 (4), 570-614. Retrieved August 27, 2021. URL: http://www.jstor.org/stable/41582855.

13. Conger, J. (1999). Charismatic and transformational leadership in organizations: An insider's perspective on these developing streams of research. Leadership Quarterly, 10, 145-179.

14. De Vries, R., Bakker-Pieper, A. \& Oostenveld, W. (2010). Leadership = Communication? The Rela tions of Leaders' Communication Styles with Leadership Styles, Knowledge Sharing and Leadership Outcomes. Journal of business and psychology, 25, 367-380. DOI: 10.1007/ s10869-009-9140-2.

15. D'Errico, F., Signorello, R., Demolin, D. \& Poggi, I. (2013). The Perception of Charisma from Voice: A Cross-Cultural Study. Proceedings - 2013 : Humaine Association Conference on Affective Computing and Intelligent Interaction, ACII. 2013, 552-557. DOI: 10.1109/ACII.2013.97.

16. Fabbi, P. (2013). The effects of charismatic communication training on leader communication effectiveness [Doctoral dissertation, Olivet Nazarene University]. URL: https://digitalcommons.olivet.edu/cgi/viewcontent.cgi?referer $=\&$ httpsredir $=1 \&$ article $=1053 \&$ context $=$ edd diss .

17. Fragouli, E. (2018) The dark-side of charisma and charismatic leadership. The Business and Management Review, 9 (4), 298-307.

18. Gutnyk, A., Niebuhr, O., \& Gu, W. (2021). Speaker Charisma Analyzed through the Cultural Lens. In 202112 th International Symposium on Chinese Spoken Language Processing (ISCSLP) IEEE. DOI: 10.1109/ISCSLP49672.2021.9362100.

19. Harrison, J., Ito, A., Bligh, M., Roland-Levy, C. (2020). A follower-centric perspective on charismatic leadership: An integrative review and agenda for future research. Routledge International Handbook of Charisma. 2020. URL: $\quad$ https://hal.archives-ouvertes.fr/hal03086811/document.

20. Heracleous, L. \& Klaering, L.A. (2014). Charismatic Leadership and Rhetorical Competence: An Analysis of Steve Jobs's Rhetoric. Group \& Organization Management, 39, 131-161. DOI: 10.1177/105960111452 5436. 
21. Jokisch, O., Iaroshenko, V., Maruschke, M., \& Ding, H. (2018). Influence of age, gender and sample duration on the charisma assessment of German speakers. In Studientexte zur Sprachkommunikation: Elektronische Sprachsignalverarbeitung (pp. 224-231). Dresden : TUDpress. Retrieved May 01, 2021. URL: http://www.essv.de/pdf/2018_224_ 231.pdf.

22. Klein, K.J., \& House, R.J. (1995). On fire: Charismatic leadership and levels of analysis. The Leadership Quarterly, 6 (2), 183-198. DOI: 10.1016/1048-9843(95)90034-9.

23. Louekari, L. (2015). Charismatic communication style in knowledge-intensive organizations [Master's thesis, Aalto University. School of Business]. Aalto University.

24. Riggio, R. \& Riggio, H. (2008). Social Psychology and Charismatic Leadership. In D. R. Forsyth,
C. Hoyt, G. Goethals (Eds.) Leadership at the crossroads: Social psychology and Leadership (pp. 30-44). Praeger.

25. Sandberg, Y. \& Moreman, C.M. (2015). Common Threads among Different Forms of Charismatic Leadership. Journal of Religion and Business Ethics, 3, Art. 19. URL: https://via.library.depaul.edu/ $\mathrm{jrbe} / \mathrm{vol} 3 /$ iss $1 / 19$.

26. Tan, H.H. \& Wee, G. (2002). The Role of Rhetoric Content in Charismatic Leadership: A Content Analysis of a Singaporean Leader's Speeches. International Journal of Organization Theory and Behavior, 5, (3/4), 317-342.

27. Towler, A.J. (2003). Effects of charismatic influence training on attitudes, behavior, and performance. 363-381.

28. Tucker, R.C. (1977). Personality and Political Leadership. Political Science Quarterly, 92 (3), 383-393. 